\title{
Hydrological Systems in the Greater Virunga Landscape: Water Quality around Mikeno Sector
}

\author{
Katcho Karume1,2, Mashimango Bagalwa ${ }^{3 *}$, Mapendano Yalire1, Katya Kazi ${ }^{1}$, \\ Espoir Mukengere Bagula², Robert Bitariho", Deogratias Nahayo5, \\ Aventino Kasangaki', James Byamukama7 \\ ${ }^{1}$ Observatoire Volcanologique de Goma, Goma, D.R. Congo \\ ${ }^{2}$ Université Evangélique en Afrique, Faculté des Sciences Agronomiques et Environnement, Bukavu, D.R. Congo \\ ${ }^{3}$ Centre de Recherche en Science Naturelles de Lwiro, Bukavu, D.R. Congo \\ ${ }^{4}$ Institute of Tropical Forest Conservation, Kabale, Uganda \\ ${ }^{5}$ Institute d'Enseignement Supérieur de Ruhengeri, Ruhengeri, Rwanda \\ ${ }^{6}$ College of Science and Technology, Mbarara University, Kampala, Uganda \\ ${ }^{7}$ Greater Virunga Transboundary Collaboration, Kigali, Rwanda \\ Email: "mashibagalwa@yahoo.fr
}

Received 4 February 2016; accepted 27 March 2016; published 30 March 2016

Copyright (C) 2016 by authors and Scientific Research Publishing Inc.

This work is licensed under the Creative Commons Attribution International License (CC BY). http://creativecommons.org/licenses/by/4.0/

(c) (i) Open Access

\begin{abstract}
Monitoring of environmental parameters is one of the highest priorities in the evaluation of environmental status of water resources and in environmental protection policy. The main objectives are to understand and evaluate the water quantity and quality in order to provide water of appropriate quality to various water users. The water quantity was assessed by the measurement of runoff or discharge at specific river cross sections using floating method for surface water and bucket and stopwatch method for springs and boreholes. The quality of river water and spring was identified in terms of its physical, chemical, and biological parameters. The analyzed data were compared with standard values recommended by WHO. Macroinvertebrates were collected in the rivers using a plankton nets and 10 minutes of sampling. Identification was made at the laboratory of Malacology. Results revealed that the quality of water obtained from sampling points is generally good to use for different domestic purposes except the Idanta River and Rwembwe borehole, which need an appropriate treatment before use. All sampling points are located far from houses and latrines, which can contribute to fecal contamination. On the different sampling points, bathing and washing clothes were observed and could constitute the source of pollution of drinking water. In Idanta and Kamira Rivers animals used water for drinking while also people use this water for domestic and drinking. In the two sampling points high values of Escherichia coli
\end{abstract}

${ }^{*}$ Corresponding author.

How to cite this paper: Karume, K., Bagalwa, M., Yalire, M., Kazi, K., Bagula, E.M., Bitariho, R., Nahayo, D., Kasangaki, A. and Byamukama, J. (2016) Hydrological Systems in the Greater Virunga Landscape: Water Quality around Mikeno Sector. Journal of Water Resource and Protection, 8, 382-396. http://dx.doi.org/10.4236/jwarp.2016.83032 
were found. No pollutant-taxa tolerant were found in the two monitored rivers for macroinvertebrates. Since water quality and quantity remain a major challenge in rural areas, the government should provide safe water to the population around Mikeno sector after treatment using suitable techniques.

\section{Keywords}

Water Quality, Quantity, Greater Virunga Landscape, Macroinvertebrates Indicators, D.R. Congo

\section{Introduction}

Pollution of drinking water sources in rural areas remains a challenge in many developing countries [1]-[5]. Many pollutants including physical, chemical and bacteriological pollution impact springs, rivers, wells and boreholes in rural area. Despite all the efforts made to develop rural water supplies, many African countries are finding it difficult to achieve the Millennium Development Goal of reducing by half the number of people without access to clean water by 2050 [5].

Water is essential for human existence, and its importance for individual health and the well-being of a nation cannot be underestimated. Notwithstanding, many people in developing countries do not have access to safe and clean drinking water or to adequate amounts of water for basic hygiene [6] [7]. This situation can lead to a variety of health problems. Contaminated water by pathogens or toxic chemicals can cause health problems such as diarrhoea, cholera, typhoid, dysentery, cancer and skin diseases [8]. Also, inadequate amounts of water for basic hygiene can contribute to poor hygiene practices, which in turn can lead to skin and eye diseases, and act as a key factor in the transmission of many diarrheal diseases.

Nowadays, $80 \%$ of the diseases are attributed to the unsafe of drinking water in poverty stricken areas. Nearly 25,000 people died of such water pollution problems everyday [9], and 1/3 of urban inhabitants in developing countries cannot get safe drinking water [10]. It is essential to carry out total health risk assessment in the safety management of drinking water quality. Through the health risk degree assessment of drinking water source, the comprehensive conclusion of water source quality, which is represented by the risk degree of health hazard, can be got directly. So, the primary and secondary of the pollutants in waters and priority setting of governance can be determined [11]. Currently these studies are necessary and helpful to understand the problems of drinking water risk and their status, and then the priority in next step can be appropriately set. Clean drinking water is fundamental to the health and welfare of the world people. It is very important to prevent water from any quality deterioration. Prevention of water pollution is more important and practical than the remediation of contaminated water. Water quality protection should start from the source, at catchments or watershed scale. Thus, the provision of safe and adequate water contributes to better health and increased individual productivity [12].

Human and natural activities affect virtually all sections of the water cycle, often with additive effects. Over time, human activities such as forest clearing, afforestation, and agriculture, have disturbing influences on the water cycle including evapotranspiration, flow regimes, groundwater table and sea level [13]. Principal threats to water resources for humans include water pollution (the contamination of surface water and groundwater reservoirs with chemicals and microorganisms) and water scarcity (the change of runoff regimes and the change of the groundwater table) [13] [14]. Research on the quality of the drinking water as a resource and a component of the environment compared to the ecological situation and factors of anthropogenic impact is actual in the framework of the priorities of ecological security in the rural area [15]. In the Mikeno sector, Virunga National Park (PNVi), except the studies of Bagalwa et al., [16] and Mbalassa et al., [17] which concentrate on Lake Eduard and tributaries waters; no studies approach the quality and quantity of drinking water consumed by population in the all region. This study therefore was carried out to assess the demand, quality and quantity of drinking water in the Mikeno sector in order to provide water of appropriate quality and quantity to various water users.

\section{Materials and Methods}

\subsection{Study Site}

The assessments have been carried out in and around PNVi National Park in Mikeno Sector, which is an impor- 
tant watershed within the Virunga Landscape. The assessments have been restricted to 4 groupements bordering the protected area system. These groupements are: Rugari, Gisigari, Bweza and Jomba in North-Kivu Province, Democratic Republic of Congo (Figure 1).

\subsection{Water Quality and Quantity Assessment}

The methods for water quality assessment combined both field-based and laboratory based methods. Description of the quality of the aquatic environment were done by using both quantitative measurements, such as physicochemical determinations and biochemical/biological tests and through semi-quantitative and qualitative descriptions such as biotic indices, visual aspects, species inventories, etc. Water chemistry analysis for specified variables was done to determine the suitability of water for different uses.

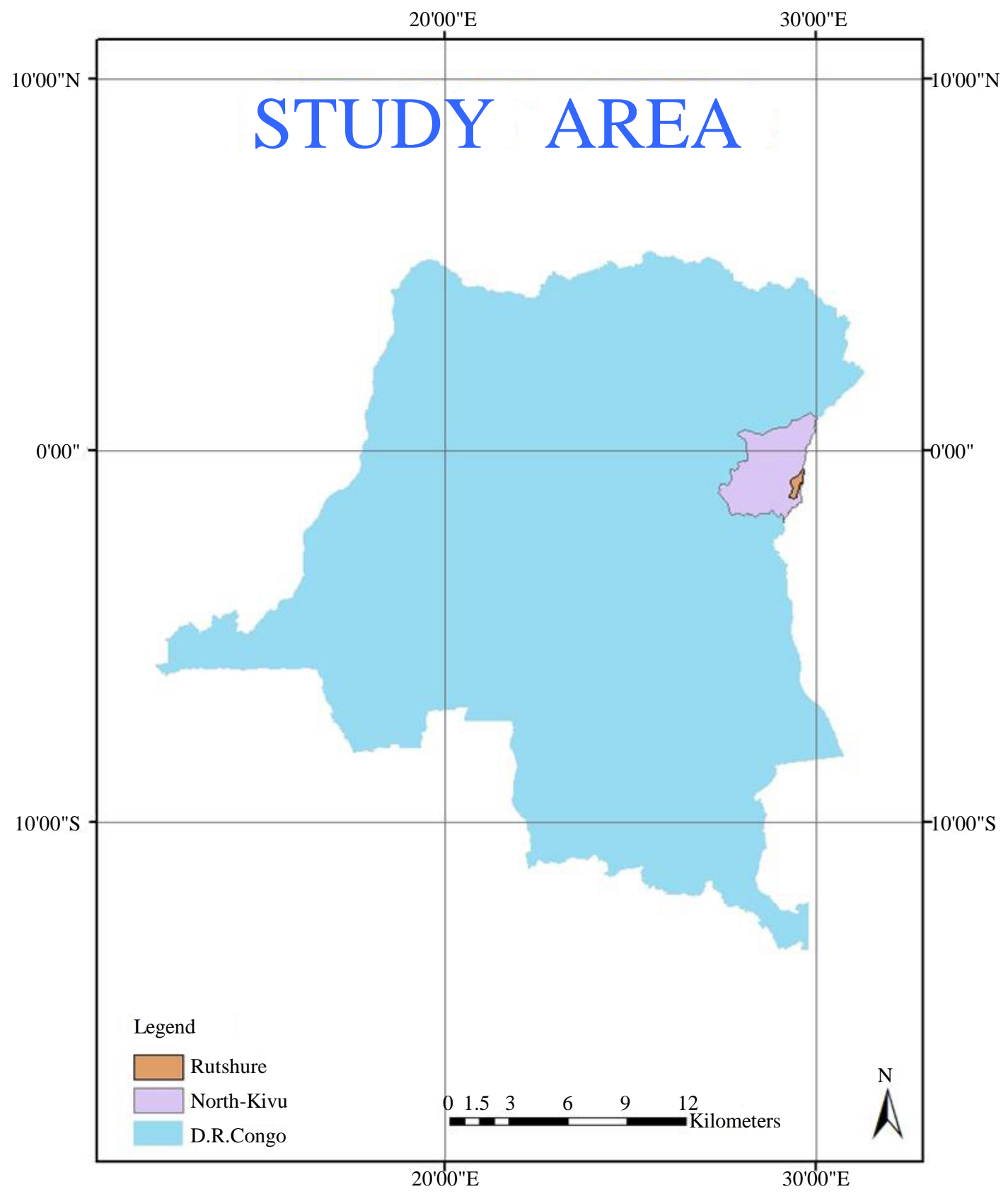

Figure 1. Study area. 


\subsubsection{Physico-Chemical Analysis}

Surface water temperature, $\mathrm{pH}$, Conductivity, Transparence, Dissolved Oxygen (DO), five-day Biological Oxygen Demand $\left(\mathrm{BOD}_{5}\right)$, Chemical Oxygen Demand (COD), Total Hardness, Calcium, Magnesium, Chloride, Sulphate, Fluoride, Hydro-carbonate, Free $\mathrm{CO}_{2}$, Total phosphorus, soluble reactive phosphorus, Total nitrogen, Ammonium, Nitrate and SS were measured in the different sites and analyzed following the procedures described in Golterman et al. [18]; APHA [19]; Wetzel and Liken [20]. Samples were collected during different times of the day. Water was collected at a depth of $30 \mathrm{~cm}$, near midstream. The temperature was measured using an YSI PROFESSIONAL PLUS. The meter sensor was dipped into the water and the temperature reading was recorded after the meter had stabilized. The $\mathrm{pH}$ was determined in-situ using the same YSI PROFESSIONAL PLUS, which was first standardized with two buffers (4 and 10) before the day of sampling. The conductivity was also measured in situ with the same equipment. Transparence of the water was determined with the aid of Secchi disc. The calibrated disc was lowered into the water and the depth at which it disappeared observed and recorded. At each sampling point, two water samples were collected in prewashed glass bottles. The level of DO in the water was determined after fixation in the field, following the iodometric Winkler's method [18] [21]. $\mathrm{BOD}_{5}$ was measured as the decrease in $\mathrm{DO}$ after incubation in the dark at $20^{\circ} \mathrm{C}$ for five days. The $\mathrm{BOD}_{5} \mathrm{in} \mathrm{mg} / \mathrm{L}$ of DO was calculated by subtracting the $\mathrm{mg} / \mathrm{L}$ of $\mathrm{DO}$ in incubated sample bottles from the DO in initial bottles [22]. Other water samples were taken in plastic bottles at the same time, for other chemical analyses (heavy metals). The plastic bottles were rinsed before overnight with $1 \mathrm{M} \mathrm{HCl}$ and then with distilled water.

The bottles were also rinsed thrice with sample water before final collection. The samples were placed in a cooler box with ice for transportation to the Goma Volcano Observatory laboratory. Analyses were not done immediately upon arrival at the laboratory; samples were stored in a refrigerator at $4^{\circ} \mathrm{C}$ with preservation as appropriate. Hydro-carbonate $\left(\mathrm{HCO}_{3}^{-}\right.$) was estimated titrimetrically using $0.1 \mathrm{~N} \mathrm{HCl}$ with phelphtalein and bromocresol as indicators (5\%). Total hardness determined by complexometric method using EDTA after added a tampon and Eriochrome T indicator. Calcium also was determined by complexometric method using mirixid indicators. Magnesium was determined by subtracting the total hardness and calcium. The Chloride was determined by titration with silver nitrate and potassium chromate indicator [18]. The sulfate was determined using gravimetrical method. TSS (mg/l) was estimated by filtration of water through analytical filter paper (Whatman 589, $185 \mu \mathrm{m}$ pore size), which was dried at $105^{\circ} \mathrm{C}$ and pre-weighed [19]. The nutrients (TN, $\mathrm{NO}_{3}^{-}, \mathrm{NH}_{4}^{+}, \mathrm{TP}$ and $\mathrm{PO}_{4}^{3-}$ ) were determined using a spectrophotometer (UNICO 1200 at $630 \mathrm{~nm}$ for nitrogen and $850 \mathrm{~nm}$ for phosphorus). All measurements were made in duplicate. Data were compared with UNECE [23], FEPA [24] and WHO [25] standards.

For other water quality variables relevant to human health such as Arsenic, and other heavy metals, water samples were delivered to INES laboratory in Musanze for analysis. The determination of heavy metals concentration in water samples was made using Atomic Absorption Spectroscopy method with the help of standard literature procedures [22] [26] [27]. Most of water samples were obtained from drinking water sources. Heavy metals determined were particularly $\mathrm{Pb}, \mathrm{Cd}, \mathrm{Fe}$, and $\mathrm{Zn}$.

\subsubsection{Bacteriological Analysis}

Samples were collected in clean, sterile polypropylene $200 \mathrm{ml}$ bottles. Before the bottles were washed with deionized water and sterilized in the oven at $60^{\circ} \mathrm{C}$ overnight. At the field bottles were washed thrice before collecting sample. All samples were kept in refrigerated cool box and transported to the laboratory. All analyses were completed at the laboratory of Bacteriology at Goma Volcano Observatory. Analyses for total coliform, fecal coliform and fecal streptococci were made in accordance with standard methods [28].

Coliforms were detected by inoculation of samples into tubes of MacConkey broth and incubation at $37^{\circ} \mathrm{C} \pm$ $1^{\circ} \mathrm{C}$ for $48 \mathrm{~h}$. The positive tubes were subcultured into brilliant green bile broth (BGBB) and were incubated at $44.5^{\circ} \mathrm{C} \pm 11^{\circ} \mathrm{C}$. Gas production in BGBB at $44.5^{\circ} \mathrm{C} \pm 1{ }^{\circ} \mathrm{C}$ was used for the detection of fecal coliform after $48 \mathrm{~h}$ incubation [29] [30]. Cultures showing no production of gas in $48 \mathrm{~h}$ were considered negative. The tubes showing gas were inoculated on eosine-methylene-blue agar; and one or more typical colonies were picked off into Brilliant Green Bile broth [31] and studied microscopically to see whether the contained organisms have the morphological and staining properties of coliform bacilli.

Fecal streptococci were detected by inoculation of water samples into Azide Dextrose broth and incubation at $37.5^{\circ} \mathrm{C} \pm 1^{\circ} \mathrm{C}$ for $24-48 \mathrm{~h}$ (APHA, 1989). Nutrient agars (NA), Salmonella-shigella agar, Thiosulphate citrate bile salt sucrose agar were used to determine heterotrophic bacterial, Salmonella, Shigella and Vibrio cholera 
respectively. All plates were incubated at $35^{\circ} \mathrm{C}$ for 24 hours. Presumptive colonies were confirmed by gram staining and biochemical reactions and each plate was given a positive or negative score. Isolates were confirmed by some conventional biochemical test [32].

Due to insecurity reasons in the region, we were not able for streams and rivers to follow an upstream to downstream gradient while for the standing water sources; a mid-source to the edge profile were followed. Sampling was done both for the wet season and the dry season.

\subsubsection{Discharge Measurement}

Stream/River discharge $(\mathrm{Q})$ is the volume of water passing a cross-section per unit of time and is generally expressed as cubic meters per second $\left(\mathrm{m}^{3} / \mathrm{s}\right)$. Discharge is velocity times cross sectional area $(\mathrm{Q}=\mathrm{VA})$. Measurement of the area was determined by measuring the width and depth of the stream. Cross-sectional area $\left(\mathrm{m}^{2}\right)$ was determined by stretching a tape across the channel to measure distance at the cross-section locations where depth is measured with a calibrated tape. The velocity in the streams at the site was determined by floating method as described by Harrelson et al., [33]; Bartram and Balance, [34]; Azanga, [35]; Bagalwa et al., [36] and Karume [37].

For source and borehole bucket and stopwatch method was used. Very easy method to estimate discharge by simply measuring the time it takes to fill a container of a known volume. A bucket of 10 liters was placed underneath in order to capture all the discharge and a stopwatch was used to estimate the time necessary to fill the bucket [38].

\subsubsection{Biological Assessment}

These assessments were carried out using benthic macro-invertebrates and Escherichia coli (E. coli) tests. Benthic macro-invertebrates were collected using a standard form hand-net of $30 \mathrm{~cm}$ wide, $20 \mathrm{~cm}$ high and $50 \mathrm{~cm}$ long with mesh size of $500 \mu \mathrm{m}$. They were collected along the river stretch in a stream direction with an effective sampling effort of 10 minutes per person [39]. The presence of stones in the riverbed and water plants were taken in the hand-net and washed in a bucket to collect macro-invertebrate attached. The collected organisms were stored and preserved in formalin $4 \%$ on the field. Species identification was made at the laboratory using the determination keys of Needhan and Needham [40], and Micha and Noiset [41]. If the species were not fund in the key, the identification was restricted to the family or genus level. Various metrics calculation indices such as number of taxa, composition, distribution and their relative abundances were used as indicators of water quality.

\section{Results and Discussion}

\subsection{Water Quantity and Quality}

Regarding water discharge, most springs generate an average of $0.001 \mathrm{~m}^{3} / \mathrm{s}$ except Kamira and Kabaya springs. For Kamira the discharge is very high. In the region Rutshuru River is the main contributor of water and the discharge was estimated to $26 \mathrm{~m}^{3} / \mathrm{s}$. In addition, results show that all the water points have considerable discharge rate, which can be used by several people in the region. The discharge for the springs and the rivers sampled during the two periods (dry and wet season) varied from one season to another. The high discharge for the spring was recorded at Kamira where the highest value for rivers was recorded at the river Rushuru $\left(26 \mathrm{~m}^{3} / \mathrm{s}\right)$. Kamira spring has several outflows and some are collected in a reservoir, which is used by population for drinking, but the quantity that flows is very high. This quantity creates a big river, which flows in the Rutshuru River. Other springs as Kabaya and Kiwerha also have sufficient discharge that population used for the daily activities, cows and for drinking (Table 1).

The biggest river in the study area is River Rutshuru one of the effluent of Lake Eduard which takes source in the wetlands and also which is filled by several springs flowing in the region by gravitation. Rivers in the study area are used also for cows, washing and for hydropower. The river flows (means for the two seasons) are sufficient to meet water demands of the population living in the area and beyond.

In the region, the use of water for irrigation, fisheries and aquaculture is not common. Best management agriculture practices are used in the mountain to maintain soil against erosion and for water conservation.

The results of mean physicochemical and bacteriological water samples for the different spring and rivers sampled showed that the water $\mathrm{pH}$ varies between 6.2 and 7.92. The $\mathrm{pH}$ is slightly acidic but within the WHO 


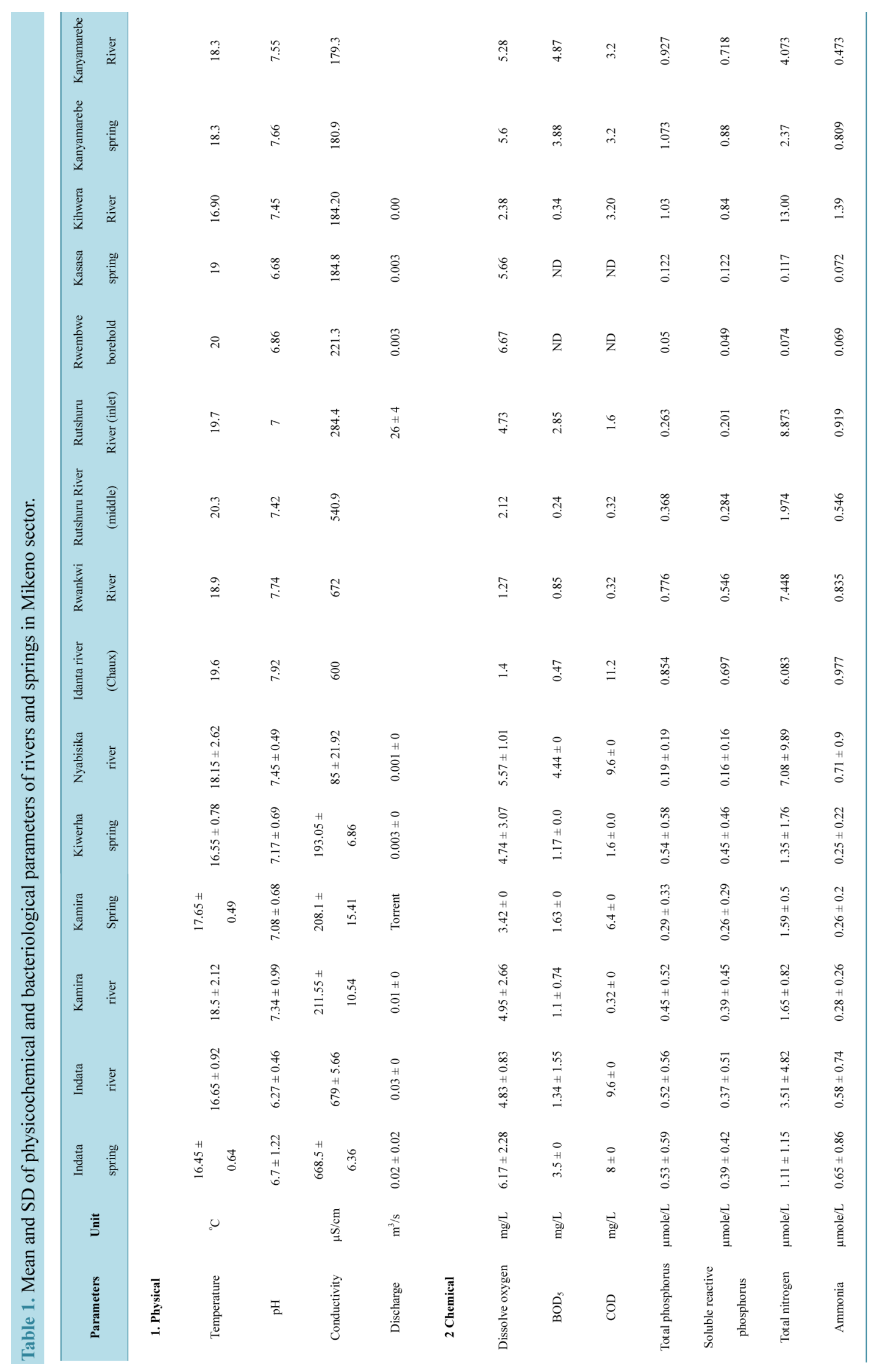




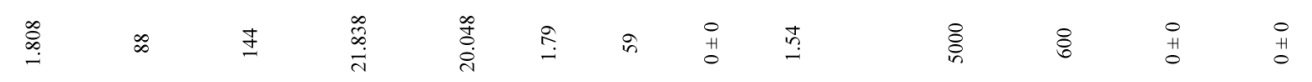

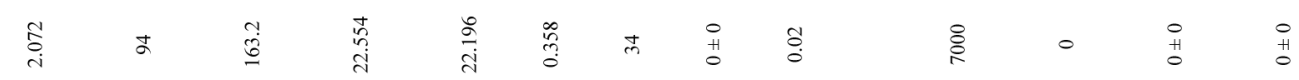

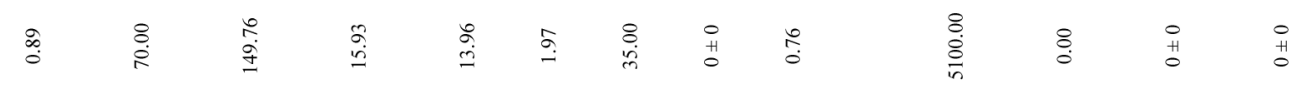

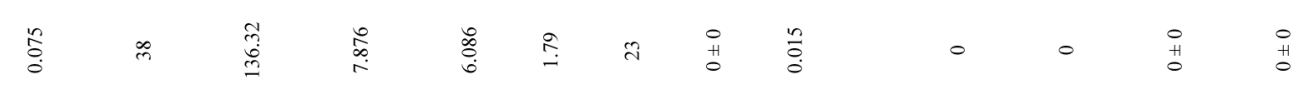

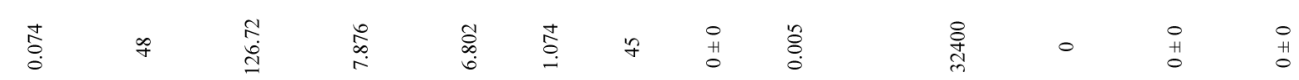

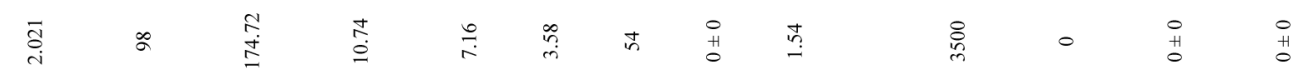

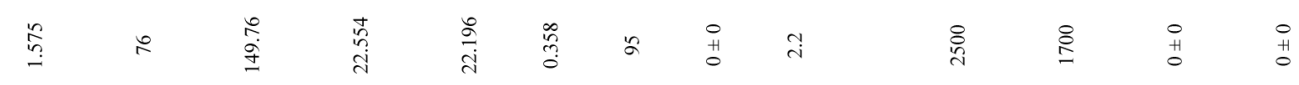

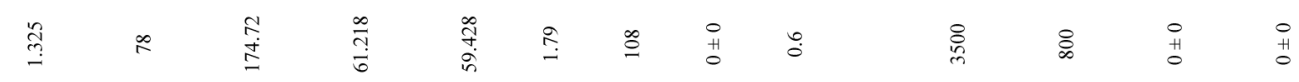

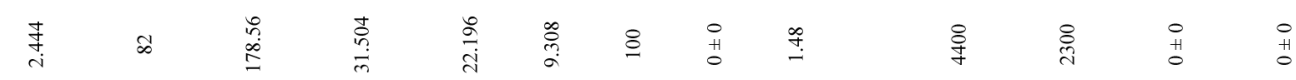

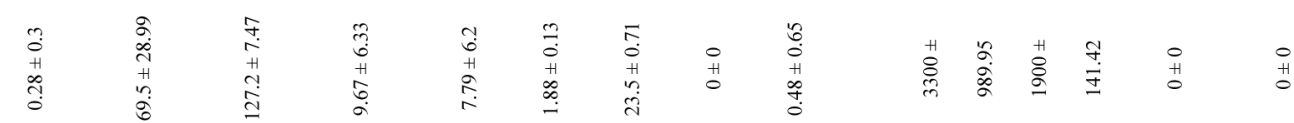

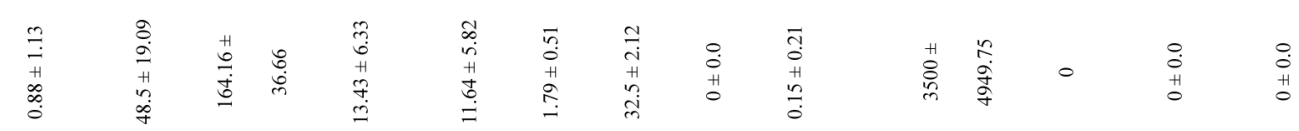

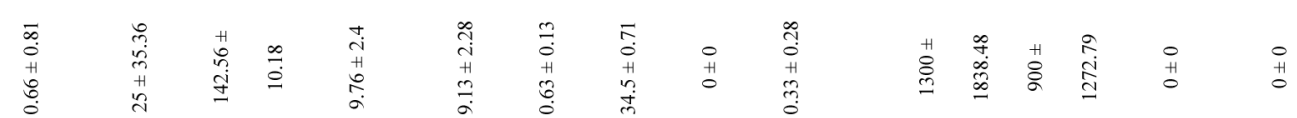

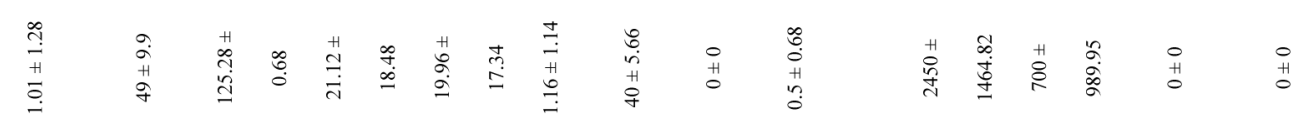

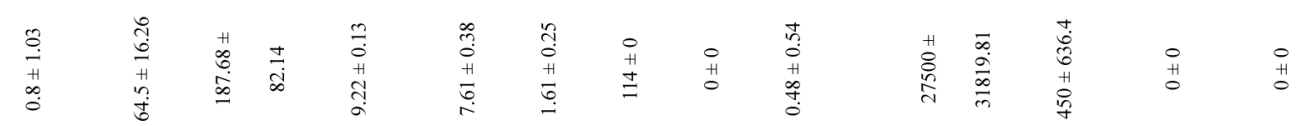

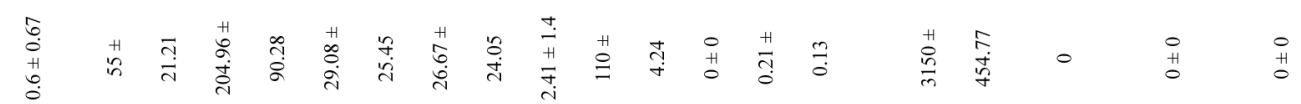

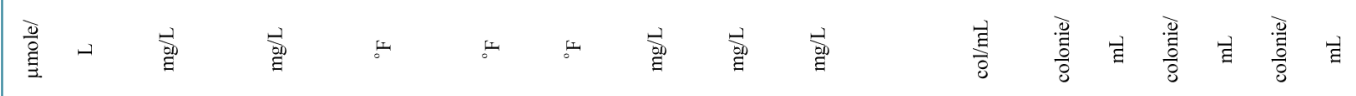

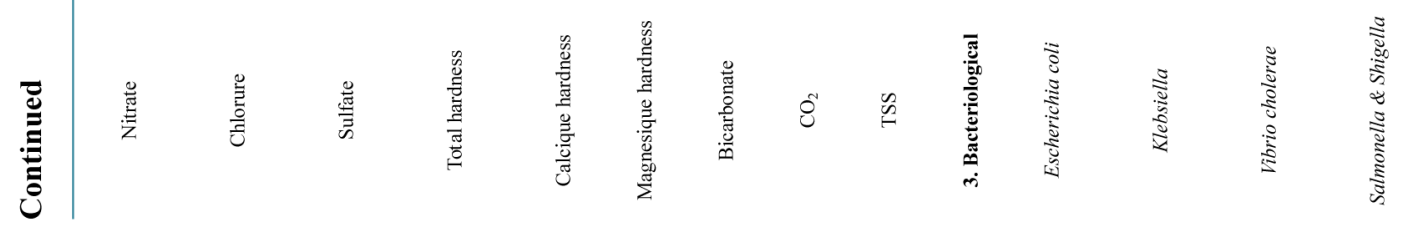


standards (6.5 to 8.5). Indata source and river has an acidic pH compared to other sources in the Mikeno sector. These values are low compared to standards for drinking water (6.5 - 8.5) and to other rivers in the Virunga sector [16] [17]. The low value recorded is probably coming from the origin of the water and can be attributed to organic matter [42] present in the surrounding region. Comparable values were also reported in Southern Ethiopia ranging between 5.7 and 6.4 [12]. These low pH values affect the taste of water [43]. The water temperature varies between 16 and $20^{\circ} \mathrm{C}$. Dissolved oxygen is an important parameter in aquatic environments. It governs the majority of biological processes in aquatic ecosystems. Its concentration is the result of physical, chemical and biological processes that produce or consume oxygen. DO was high in all the sampling points and the high saturation shows that aeration was high when 50\% during the sampling period. The low dissolved oxygen was recorded in river Idanta. The values recorded in all the sampling points were within the standards limit for drinking water [44]. DO is a measure of the degree of pollution by organic matter. It is the destructive power of organic substance as well as the self purification capacity of the water body [45].

The conductivity of natural water ranges from 50 to $1500 \mu \mathrm{S} / \mathrm{Cm}$. The waters sampled from the region have conductivities between that range except for Indata River and spring (675 and $673 \mu \mathrm{S} / \mathrm{Cm}$ ) where high values are recorded. This conductivity indicates the presence of dissolved ions in the water. The high conductivity in the river and the Indata source would be probably due to the nature of the mother rock from where the water comes. EC of all the sampling point was in the range of standard guideline for drinking water $(20-1500 \mu \mathrm{S} / \mathrm{cm})$ and also in the range of other waters in the Virunga sector [16] [46].

The waters sampled in this region are well oxygenated with variation rate of dissolved oxygen varying between 1.2 to $7.78 \mathrm{mg} / \mathrm{L}$. The concentrations of the other parameters like alkalinity (23 - $114 \mathrm{mg} / \mathrm{L}$ ), sulphate (121 - $140 \mathrm{mg} / \mathrm{L})$, chloride $(0-49 \mathrm{mg} / \mathrm{L})$, hardness $\left(5.19^{\circ} \mathrm{F}\right.$ to $\left.11.09^{\circ} \mathrm{F}\right)$, calcium hardness $\left(3.4^{\circ} \mathrm{F}\right.$ to $\left.9.6^{\circ} \mathrm{F}\right)$ and magnesium hardness $\left(0.3^{\circ} \mathrm{F}\right.$ to $\left.1.79^{\circ} \mathrm{F}\right)$ are within the WHO standards.

The chemical oxygen demand (COD) can be used to measure the whole amount of organic compounds in water. It is based on the fact that all organic matter can be oxidized by the action of potassium permanganate under acidic conditions [18]. COD values in the sampling points were high compared to standards of drinking water. The maximum allowed value of chemical oxygen demand (COD) is $10 \mathrm{mg} / \mathrm{l}$ in drinking water [47]. The present samples have registered values between 17.6 and $34.4 \mathrm{mg} / \mathrm{l}$. These values are higher than values expected for good quality potable water. Biological Oxygen demand $\left(\mathrm{BOD}_{5}\right)$ was only measured in rivers and shown low values compared to other studies in the Virunga sector [16]. The comparison of the 2 variables (COD and BOD) can provide information about how much and how strength the organic materials in the water sample are. The biochemical oxygen demand $\left(\mathrm{BOD}_{5}\right)$ in the rivers and spring are low. This shows that the bacteria to decompose partially or completely oxidize the biochemical oxidizable materials in the water are relatively few. The chemical oxygen demand (COD) varies between 17.6 and $34.4 \mathrm{mg} / \mathrm{L}$. This is the quantity of oxygen necessary for the degradation by chemical means, carried out using a strong oxidant, organic compounds present in water. The total hardness value lies between 51.91 and $110.9 \mathrm{mg} / \mathrm{L}$ (500 mg/L), calcium hardness lies between 34.01 - $99.66 \mathrm{mg} / \mathrm{L}(200 \mathrm{mg} / \mathrm{L})$ and magnesium hardness between 3.58 - $17.9 \mathrm{mg} / \mathrm{L}$ varied from sample to sample but remained in the range of respectively standards. The limiting values prescribed by WHO are much greater than reported values.

A significant presence of anions like chloride and sulfate is also observed in the water samples under investigation. The concentration of chloride and sulfate in the samples range from 0 - $53 \mathrm{mg} / \mathrm{l}$ and 121.92 - $141.12 \mathrm{mg} / \mathrm{l}$ respectively. The concentrations of chloride and sulfate in the different samples fall well within the prescribed limit by WHO [44]. The sulfate concentrations in the different sampling points are high compared to the data obtained in the Virunga sector [16].

Concentrations of TP (0.05 - $0.128 \mu$ mole/L), SRP (0.01 - $0.122 \mu$ mole/L), TN (0.074 - $0.124 \mu \mathrm{mole} / \mathrm{L})$, $\mathrm{NH}_{4}^{+}(0.045-0.114 \mu \mathrm{mole} / \mathrm{L})$ and $\mathrm{NO}_{3}^{-}(0.03-0.096 \mu$ mole/L) in the different sampling points are low compared to standards of drinking waters. Natural nitrate concentrations in groundwater range from 0.1 to 10 $\mathrm{mg} / \mathrm{l}$ [48]. Nitrate in concentration greater than $45 \mathrm{mg} / \mathrm{l}$ is undesirable in domestic water supplies because of the potential toxic effect on young infants. Methemoglobinemia is a disease caused by nitrate, which is converted to nitrite in the intestines [48]. The safe nitrate limit for domestic water is set at $45 \mathrm{mg} / \mathrm{l} \mathrm{by} \mathrm{WHO} \mathrm{[44].} \mathrm{Nitrate}$ cannot be removed from water by boiling but must be treated by distillation. Nitrate was low in most of the sampling points in Mikeno sector. Phosphorus, an element necessary for plant growth, is the main cause of eutrophication and of water quality deterioration. Even minimal phosphorus content (some $0.25 \mathrm{of} \mu \mathrm{mol} / \mathrm{L}$ ) can constitute a dangerous pollutant. Thus, according to the ECE (Economic Commission for Europe of the United 
Nations), [49] classification of surface water, water is considered fairly eutrophic as of $0.64 \mu \mathrm{mol} / \mathrm{L}$.

In this study, only two sampling points were found having coliform bacteria. The sampling points concerned are river Idanta and Rwembwe borehole. The guidelines for drinking water quality proposed by WHO [44] recommend that water for drinking couldn't contain total and/or fecal coliform bacteria. The result indicated that bacteriological water quality is a concern in this area. It must be clear that the provision of water services must result in health improvements to users as an ultimate goal. However, when this goal is compromised and user's health is affected, they commonly resort to their traditional unsafe sources or travel longer distances to find other safe water sources.

Nitrogen $(\mathrm{N})$ and phosphorus $(\mathrm{P})$ are nutrients essential to plants. Concentrations of nitrates and phosphates induce excessive eutrophication (suffocation of aquatic life). The concentrations in nitrite $\left(\mathrm{NO}_{2}^{-}\right)$, nitrate $\left(\mathrm{NO}_{3}^{-}\right)$, ammonia $\left(\mathrm{NH}_{3}\right)$ and ammonium $\left(\mathrm{NH}_{4}^{+}\right)$, phosphate $\left(\mathrm{PO}_{4}^{3-}\right)$, nitrogen $(\mathrm{N})$ and phosphorus $(\mathrm{P})$ are therefore important parameters for monitoring the quality of surface water. The concentration of total nitrogen, ammonium, nitrate, phosphate and total phosphorus are low in all samples.

The bacteriological analysis shows the presence of Escherichia coli in all the sampling water with different values. This situation was also reported in Lake Eduard and tributaries [16]. Sampling was done in heavy rain and the presence of runoff can probably be the source of contamination. This is also the same for Klesiella found in some samples. But the Vibrio cholera, salmonella and shigella were not found in the samples during this sampling period. These confirm the presence of fecal contamination of water during the sampling period. As Vibrio cholera, salmonella and shigella were reported in samples in Lake Eduard and tributaries [16], the absence of them during this period is not a guarantee for their eradication. Regular sampling in the different sites is necessary for the drinking water and water for other uses.

Generally, the results showed that most of the measured values of these parameters are within the WHO guidelines for drinking water quality [44] for springs. From 14 water points, only 5 are springs, the rest are rivers where people fetch water for domestic use. Samples were collected and analyzed during rain and dry seasons. Physicochemical parameters varied from one season to the other. Generally the highest values were recorded during the dry season in many samples except for the EC, TN and DO for some sites. These changes in water quality may be attributed to the local climatic conditions and water exchange mechanisms. But, the values were in the range of standards water quality for drinking [44]. It is known that the quality of surface water within a region is governed by both natural processes (such as precipitation rate, weathering processes and soil erosion) and anthropogenic effects (such as urban, industrial and agricultural activities and human exploitation of water resources) [50].

\subsection{Heavy Metal in Sampling Water}

The results of analysis of heavy metal in sampling water are presented in Table 2 below.

Table 2 indicates that $\mathrm{Pb}$ is not detectable in all the water samples during the study period. Iron $(\mathrm{Fe})$ is not observed (Rembwe and Kamira spring) or very low (in others) in whole analyzed samples, Cadmium and Zinc (Zn) are the heavy metal recorded except in Indata River. The highest value of $\mathrm{Cd}$ was recorded at Kiwera spring while the highest value of Zn was recorded at Indata spring. All the values were lower than the standards recommended by WHO [44]. Any heavy metal was recorded in Indata River.

Table 2. Concentration of Heavy Metals in sampling water.

\begin{tabular}{ccccc}
\hline Sampling location & $\mathbf{C d}(\boldsymbol{\mu g} / \mathbf{m l})$ & Fe $(\boldsymbol{\mu g} / \mathbf{m l})$ & $\mathbf{Z n}(\boldsymbol{\mu g} / \mathbf{m l})$ & $\mathbf{P b}(\boldsymbol{\mu g} / \mathbf{m l})$ \\
\hline Indata spring & 0.004 & ND & 0.232 & 0.000 \\
Kamira 1 & 0.001 & ND & 0.028 & 0.000 \\
Kiwera spring & 0.005 & ND & 0.024 & 0.000 \\
Indata River I.R & ND & ND & ND & 0.000 \\
Gasaro/Burere source & 0.004 & ND & 0.155 & 0.000 \\
Rembwe & 0.004 & 0.000 & 0.022 & 0.000 \\
Kasasa spring & 0.002 & ND & 0.009 & 0.000 \\
Kamira spring & 0.002 & 0.000 & 0.118 & 0.000 \\
Standards WHO [45] & 0.003 & 0.05 & 0.01 & 0.000 \\
\hline
\end{tabular}

Legende: $\mathrm{ND}=$ not detectable. 
Table 3. Macro invertebrates distribution in rivers in Mikeno sector.

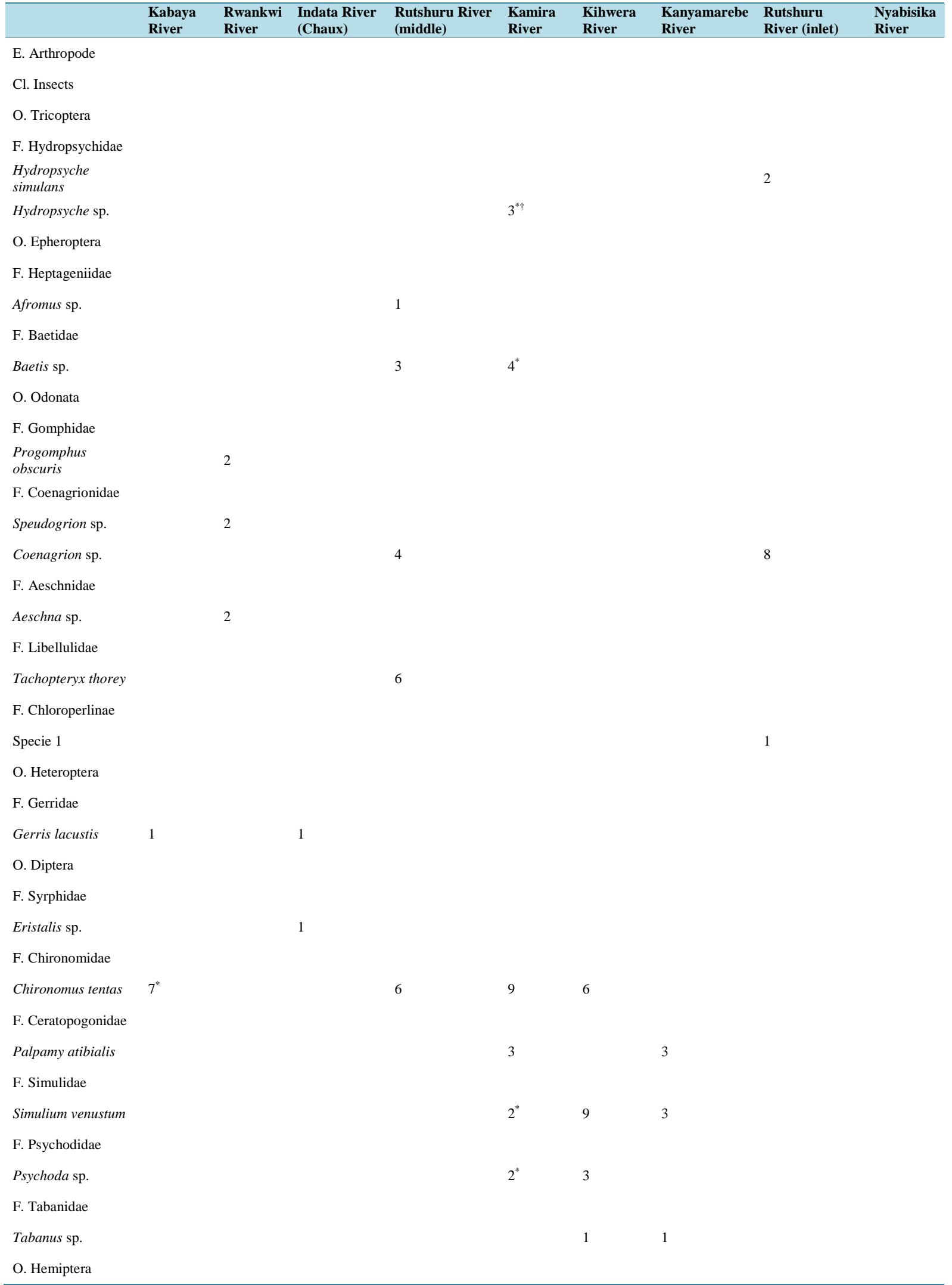




\section{Continued}

F. Nepidae

Ranatra fusca

F. Naucoridae

Pelocoris femoratus

O. Coleoptera

F. Haliplidae

Specie 2

1

F. Amphizoidae

Amphizoa lecontei $\quad 1^{*} \quad 1$

Cl. Arachnidae

O. Areneides

Agyronecta

aquatica

1

Cl. Cristacea

O. Decapoda

F. Potadomidae

Potagetum sp.

O. Amphipodes

F. Honstoridae

Palaemonetes sp.

E. Annelida

Cl. Oligocheta

O. Lumbriculida

F. Lumbriculidae

Lumbriculis

inconstans

1

Cl. Huridinae

O. Rhynchobdellida

F. Gloniphonidae

Hoemopis

sanguisuga

E. Nemathelminthe

Cl. Gordiace

O. Gordidae

F. Nematophora

Gordius sp.

1

E. Mollusca

Cl. Gastroda

O. Basommatophora

F. Sphaeridae

Pisidium

casernatum

F. Ancylidae

Ferrissia sp.

Specific richness $\quad 4$

$8 \quad 3$

8

$8 \quad 8$

$8 \quad 4$

4

0

Legend: ${ }^{*}$ Collected in rainy season; ${ }^{\dagger}$ Collected in dry season. 
There are various sources of heavy metals in the water bodies; some originate from anthropogenic activities like draining of sewerage, dumping of Hospital wastes and recreational activities. Conversely, metals also occur in small amounts naturally and may enter into aquatic system through leaching of rocks, airborne dust, forest fires and vegetation [51] [52]. As heavy metals cannot be degraded, they are continuously being deposited and incorporated in water, sediment and aquatic organisms [53], thus causing heavy metal pollution in water bodies.

Heavy metals have been used as indices of pollution because of their high toxicity to human and aquatic life [54]. The concentration of lead in water throughout the sampling site was not detectable and was lower than the WHO [44] drinking water limit of $0.01 \mathrm{mg} / \mathrm{L}$. The source of lead concentration in the inflowing consists of various wastes from industrial and domestic effluents, including automobile garages and car wash, which discharge mixtures of oil and car washing into the stream. Such activities may contribute to the increase of lead contamination in surface water or in ground water [55]. In the sampling area this source is much reduced and is probably the reason that lead is not recorded in the sampling water. Cadmium concentration was below detection limit of $0.01 \mathrm{mg} / \mathrm{L}$ as indicated in the results in different sites. Iron is common constituent in ground water. It is present in water either as soluble ferrous iron or insoluble ferric iron [56]. Taste of iron is not usually noticeable at iron concentrations below $0.5 \mathrm{mg} / \mathrm{L}$. Although iron has got little concern as a health hazard, it still considered as a nuisance in excessive quantities [55]. Long time consumption of drinking water with a high concentration of iron can lead to liver diseases (Hemosiderosis).

The levels of the heavy metals detected are lower than WHO standards for drinking water and have no effect on the health of users in the study area. But chronic adverse health effects due to bioaccumulation and long term used of water can cause effect on the health. There is need of continual monitoring of water quality in the study area to ensure safety of users.

\subsection{Macroinvertebrates in Rivers}

Distribution of macroinvertebrates in the different rivers across the Mikeno sector is presented in Table 3.

During the sampling period, 29 species were identified in the different rivers in the Mikeno sector. Some species are indicators of water pollution such as Chironomus tentas and Eristalis sp. [41] and are present in some rivers. This shows that the aquatic ecosystem seems to become polluted and other macroinvertebrates disappeared in rivers. When we compare taxa richness for the 2 seasons, the high diversity was recorded in dry season than in wet season. Some species were found only in the dry season. The species identified in the sampling points are not pollutant tolerant species [57]. Chironomids midge lavae were the most abundant organisms found in Idanta River while Baetis were the most in Kamira River.

\section{Conclusion}

Water quality and quantity in rural area in many African countries remain a serious deal and a priority action. This study contributes to understanding and evaluating the water quantity and quality in order to provide water of appropriate quality to various water users in Mikeno sector, Virunga landscape. The quality of water obtained from these sampling points is generally good to use for different domestic purposes except the river Idanta and Rwembwe borehole, which need an appropriate treatment before use. Since water quality and quantity remain a major challenge in rural areas, the government should capture the water in the different sampling points and provide safe water to the population around Mikeno sector. Water quality remains a sustainable development challenge in the rural areas of Mikeno sector and a lot more has to be done in the area of water pollution management.

\section{References}

[1] Mwendera, E.J. (2006) Rural Water Supply and Sanitation (RWSS) Coverage in Swaziland: Toward Achieving Millennium Development Goals. Physics and Chemistry of the Earth, 31, 681-689. http://dx.doi.org/10.1016/j.pce.2006.08.040

[2] Zhu, K., Zhang, L., Hart, W., Liu, M. and Chen, H. (2004) Quality Issues in Harvested Rainwater in Arid and SemiArid Loess Plateau of Northern China. Journal of Arid Environments, 57, 487-505. http://dx.doi.org/10.1016/S0140-1963(03)00118-6

[3] Sadeghi, G.H., Mohammadian, M., Nourani, M., Peyda, M. and Eslami, A. (2007) Microbiological Quality Assessment of Rural Drinking Water Supplies in Iran. Journal of Agriculture \& Social Sciences, 3, 31-33. 
[4] Traichaiyaporn, S. and Chitmanat, C. (2008) Water Quality Monitoring in Upper Ping River, Thailand. Journal of Agriculture \& Social Sciences, 4, 31-34.

[5] Gamedze, K., Tevera, D.S. and Fadiran, A.O. (2012) Water Quality Assessment of Various Sources in Rural Areas in the Lowveld Region of Swaziland. Current Research Journal of Social Sciences, 4, 99-102.

[6] Fewtrell, L., Prüss-Üstün, A., Bos, R., Gore, F. and Bartram, J. (2007) Water, Sanitation and Hygiene: Quantifying the Health Impact at National and Local Levels in Countries with Incomplete Water Supply and Sanitation Coverage. WHO, Geneva.

[7] Prüss-Üstün, A. and Corvalán, C. (2006) Preventing Disease through Health Environments. Towards an Estimate of the Environmental Burden of Disease. WHO, Geneva.

[8] WHO (1997) Guidelines for Drinking-Water Quality, Volume 3: Surveillance and Control of Community Water Supplies. 2nd Edition, WHO, Geneva.

[9] Li, E.X. and Ling, B. (2006) Effect of Water Pollution on Human Health. Sanitary Engineering of China, 5, 3-5.

[10] Yin, Y.R. and Deng, Z.L. (2006) Analysis on Relationship between Drinking Water and Health. Scientific and Technological Information of China, 219-221.

[11] Ni, F., Liu, G., Ye, J., Ren, H. and Yang, S. (2009) ArcGIS-Based Rural Drinking Water Quality Health Risk Assessment. Journal of Water Resource and Protection, 1, 351-361. http://dx.doi.org/10.4236/jwarp.2009.15042

[12] Haylamicheal, I.D. and Moges, A. (2012) Assessing Water Quality of Rural Water Supply Schemes as a Measure of Service Delivery Sustainability: A Case Study of Wondo Genet District, Southern Ethiopia. African Journal of Environmental Science and Technology, 6, 229-236. http://dx.doi.org/10.5897/AJEST12.010

[13] Urama, K.C. and Ozor, N. (2010) Impacts of Climate Change on Water Resources in Africa: The Role of Adaptation. Climate Adaptation, $29 \mathrm{p}$.

[14] Stolberg, F., Borysova, O., Mitrofanov, I., Barannik, V. and Eghtesadi, P. (2003) Caspian Sea. GIWA Regional Assessment 23. Global International Waters Assessment (GIWA).

[15] Andriuca, V. (2010) Assessment of the Ecological Situation and the State of the Drinking Water Quality in Rural Areas of the Dniester River Basin. Present Environment and Sustainable Development, 4, 57-68.

[16] Bagalwa, M., Yalire, M., Balole, E. and Karume, K. (2014) A Preliminary Assessment of Physico Chemical and Bacteriological Characteristics of Lake Edward and Majors Tributaries Rivers, Democratic Republic of Congo. Scholars Academic Journal of Biosciences (SAJB), 2, 236-245.

[17] Mbalassa, M., Bagalwa, M., Nshombo, M. and Kateyo, M. (2014) Assessment of Physicochemical Parameters in Relation with Fish Ecology in Ishasha River and Lake Edward, Albertine Rift Valley, East Africa. International Journal of Current Microbiology and Applied Sciences, 3, 230-244.

[18] Golterman, H.L., Clymo, R.S. and Ohnstad, M. (1978) Methods for Physical and Chemical Analysis of Fresh Waters. Blackwell, London, 213 p.

[19] APHA (American Public Health Association) (1989) Standard Methods for the Examination of Water and Wastewater. 18th Edition, APHA, Washington DC, 1587 p.

[20] Wetzel, R.G. and Likens, G.E. (2000) Limnological Analysis. Springer, Berlin, 429 p. http://dx.doi.org/10.1007/978-1-4757-3250-4

[21] Olapande, O.J. and Omitoyin, B.O. (2012) Anthropogenic Pollution Impact on Physico-Chemical Characteristics of Lake Kivu, Rwanda. Scholarly Peer Reviewed, 12, 6517-6536.

[22] Olapande, O.J. (2011) Trace Metal Pollution and Physicochemical Characteristics of Lake Kivu, Rwanda. Global Journal of Environmental Research, 5, 56-64.

[23] UNECE (1994) Standard Statistical Classification of Surface Freshwater Quality for the Maintenance of Aquatic Life. In: Readings in International Environment Statistics, United Nations Economic Commission for Europe: United Nations, New York and Geneva, 53-64.

[24] FEPA (Federal Environmental Protection Agency) (1991) Guidelines and Standards for Environmental Pollution Control in Nigeria, Federal Environmental Protection Agency Regulation 1991 on Pollution Abatement in Industries and Facilities Generated Wastes. 78(42): 38 p.

[25] WHO (1993) Guidelines for Drinking Water Quality. World Health Organization, Geneva, 489 p.

[26] Podda, F., Zuddas, P., Minacci, A., Pepi, M. and Baldi, F. (2000) Heavy Metal Coprecipitation with Hydrozine $\left[\mathrm{Zn}_{5}\left(\mathrm{CO}_{3}\right)_{2}(\mathrm{OH})_{6}\right]$ from Mine Waters Caused by Photosynthetic Micro-Organisms. Applied and Environmental Microbiology, 66, 5092-5098.

[27] Welz, B. (1985) Atomic Absorption Spectroscopy. VCH, Weinheim and Deerfield Beach, 506 p.

[28] APHA (American Public Health Association) (1995) Standard Methods for the Examination of Water and Wastewater. 
19th Edition, American Public Health Association, Washington DC.

[29] Collins, C.H. and Lyne, M.P. (1976) Microbiological Methods. Butterworth and Co publishers Ltd., London, Boston, $524 \mathrm{p}$.

[30] Bakare, A.A., Lateef, A., Amuda, O.S. and Afolabi, R.O. (2003) The Aquatic Toxicity and Characterization of Chemical and Microbiological Constituents of Water Samples from Oba River, Odo-oba, Nigeria. Asian Journal of Microbiology, Biotechnology and Environmental Sciences, 5, 11-17.

[31] Coyne, M.S. and Howell, J.M. (1994) The Faecal Coliform/Faecal Streptococci Ratio (FC/FS) and Water Quality in the Bluegrass Region of Kentucky. Soil Science News \& Views, 15, 4.

[32] SCA (Standing Committee of Analysts) (2002) The Microbiology of Drinking Water. Part 1-Water Quality and Public Health. Methods for the Examination of Waters and Associated Materials. Environment Agency.

[33] Harrelson, C.C., Rawlins, C.L. and Potyondy, J.P. (1994) Stream Channel Reference Sites: An Illustrated Guide to Field Technique. Gen. Tech. Rep. RM-245. US Department of Agriculture, Forest Service, Rocky Mountain Forest and Range Experiment Station, Fort Collins, 61 p.

[34] Bartram, J. and Balance, R. (1996) Water Quality Monitoring: A Practical Guide to the Design of Freshwater Quality Studies and Monitoring Programmes. Chapman \& Hall, London.

[35] Azanga, E. (2013) Sediment and Nutrient Hotspot Areas Dynamics in Selected Micro-Catchment of the Lake Tanganyika Basin in Democratic Republic of Congo. Master Thesis, Makerere University, Kampala, 97 p.

[36] Bagalwa, M., Zirirane, N., Pauls, S.U., Karume, K., Ngera, M., Bisimwa, M. and Mushagalusa, N. (2012) Aspects of the Physico-Chemical Characteristics of Rivers in Kahuzi-Biega National Park, Democratic Republic of Congo. Journal of Environmental Protection, 3, 1590-1595. http://dx.doi.org/10.4236/jep.2012.311175

[37] Karume, K. (2006) Biomass and Hydropower Potential and Demand in the Albertine Rift Region. PhD Thesis, Makerere University, Kampala.

[38] Michaud, J.P. and Wierenga, M. (2005) Estimating Discharge and Stream Flows. A Guide for Sand and Gravel Operators. Ecology Publication Number 05-10-070, 37 p.

[39] Olivier, L. and Scheiderman, M. (1956) Method for Estimation of the Density of Aquatic Snail Population. Experimental Parasitology, 5, 109-117. http://dx.doi.org/10.1016/0014-4894(56)90008-X

[40] Needham, J.G. and Needham, P.R. (1962) A Guide to the Study of Freshwater Biology. Holden Day, Inc, San Francisco.

[41] Micha, J.C. and Noiset, J.L. (1982) Evaluation biologique de la pollution de ruisseaux et rivières par les macro-invertébrés aquatiques. Probio Revue, 5, 142 p.

[42] Meyberck, M., Friedrich, G., Thomas, R. and Chapman, D. (1996) Rivers Water Quality Assessments: A Guide to the Use of Biota, Sediments and Water in Environment Monitoring. Chapman Edition, 2nd Edition, E \& FN Spon, London, 59-126.

[43] Hoko, Z. (2008) An Assessment of Quality of Water from Boreholes in Bindura District, Zimbabwe. Physics and Chemistry of the Earth, 33, 824-828. http://dx.doi.org/10.1016/j.pce.2008.06.024

[44] WHO (2004) Guidelines for Drinking-Water Quality. 3rd Edition, Vol. 1, Recommendations, World Health Organization, Geneva.

[45] Environment Canada (1987) Canadian Water Quality Guidelines [with Updates]. Prepared by the Task Force on Water Quality Guidelines of the Canadian Council of Resource Ministers, Environment Canada, Ottawa.

[46] Ali, S.S., Salam, A., Azeem, A., Shafique, M. and Khan, B.A. (2000) Studies on the Effect of Seasonal Variations on Physical and Chemical Characteristics of Mixed Water from Rivers Ravi and Chenab at Union Site in Pakistan. Journal of Research (Science)—Bahauddin Zakariya University, Multan, 2, 1-17.

[47] Patil, N., Ahmed, A., Sureshbaba, H., Kottureshwar, N.M., Jayashree, M. and Nijalingappa, J. (2010) Study on the Physico-Chemical Characteristics of Ground Water of Gulbarga City (Karnataka). International Journal of Applied Biology and Pharmaceutical Technology, 1, 518-523

[48] Adeyemo, O.K., Ayodeji, I.O. and Aiki-Raji, C.O. (2002) The Water Quality and Sanitary Conditions in a Major Abbatoir (Bodija) in Ibadan, Nigeria. Africa Journal of Biomedical Research. Ibadan Biomedical Communications Group, 1-2, 51-55.

[49] EEC (European Economic Community) (1993) European Community Standards for Surface Waters Used for Portable Abstractions. Directive 76/464/EEC. EEC, Brussels.

[50] Shetty, S., Tharavathy, N.C., Lobo, R.O. and Shafakatullah, N. (2013) Seasonal Variation in the Physico-Chemical Characteristics along the Upstream of Tungabhadra River, Western Ghats, India. International Journal of Plants, Animals and Environmental Sciences, 3, 242-246. 
[51] Fernandez, L.G. and Olalla, H.Y. (2000) Toxicity and Bioaccumulation of Lead and Cadmium in Marine Protozoan Communities. Ecotoxicology and Environmental Safety, 47, 266-276. http://dx.doi.org/10.1006/eesa.2000.1944

[52] Ogoyi, D.O., Mwita, C.J., Nguu, E.K. and Shiundu, P.M. (2011) Determination of Heavy Metal Content in Water, Sediment and Microalgae from Lake Victoria, East Africa. The Open Environmental Engineering Journal, 4, $156-161$. http://dx.doi.org/10.2174/1874829501104010156

[53] Linnik, P.M. and Zubenko, I.B. (2000) Role of Bottom Sediments in the Secondary Pollution of Aquatic Environments by Heavy Metal Compounds. Lakes and Reservoir: Research and Management, 5, 11-21. http://dx.doi.org/10.1046/j.1440-1770.2000.00094.x

[54] Omoigberale, M.O. and Ogbeibu, A.E. (2005) Assessing the Environmental Impacts of Oil Exploration and Production on the Osse River, Southern Nigeria, I. Heavy Metals. African Journal of Environmental Pollution and Health, 4, 27-32.

[55] Mwegoha, W.J.S. and Kihampa, C. (2010) Heavy Metal Contamination in Agricultural Soils and Water in Dar es Salaam City, Tanzania. African Journal of Environmental Science and Technology, 4, 763-769.

[56] Chandana, J., Priti, S. and Pratima, J. (2014) Evaluation of Physico-Chemical and Microbial Properties of Ground Water Recharged through Water Harvesting System in Gwalior, MP, India. Research Journal of Chemical Sciences, 4, 72-75.

[57] Vernaux, J. and Tuffery, G. (1967) Une méthode zoologique pratique de détermination de la qualité biologique des eaux courantes. Indices biologiques. Annuaire des Sciences de l’Université de Besançon, (Zoologie), 3, 79-90. 